pasientpopulasjonene i Sverige. Kapitlene har noe varierende kvalitet, men spesielt kapitlene om sarkoidose og hoste er glitrende gode. Boken er mer innholdsrik enn de to norske lærebøkene som er på markedet på samme fagområde. Det må ha vært en stor utfordring for redaktørene å redigere denne læreboken med så mange forfattere, men de har lyktes på en glimrende måte. Den kan anbefales til leger under utdanning i spesialiteten lungesykdommer og til spesialister i lungesykdommer.

\section{Helseøkonomi på svensk}

Anell A.

\section{Hälsoekonomi}

122 s, tab, ill. Lund: Studentlitteratur, 2009. Pris SEK 204

ISBN 978-91-44-04843-7

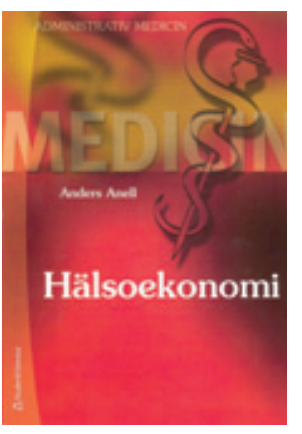

Målgruppen er beslutningstakere på alle nivåer $i$ helsetjenesten. Boken er skrevet på svensk, og mange tall og eksempler er hentet fra Sverige, men det meste av stoffet er aktuelt også for norske

lesere. Den er lettlest og krever ingen forkunnskaper i økonomi.

Det er tre hovedtemaer: ressurstilgang og finansiering av helsetjenesten, betalingsordninger for leger og sykehus samt prioritering og økonomisk evaluering. Selv om utgangspunktet er svenske forhold, gjøres en rekke internasjonale sammenlikninger. Omtalen av egenandeler og forsikringsordninger tyder på at helsedebatten i Sverige ikke er meget forskjellig fra den i Norge. Det samme gjelder spørsmålet om betaling av leger og sykehus. Personlig savnet jeg større oppmerksomhet omkring hvor lite god forskning det er på området og at helsepersonellet ikke synes å la seg styre så lett gjennom incentiver. Gjennomgangen av økonomisk evaluering er ryddig, men noen lesere vil nok savne de mange innvendinger som er reist mot kvalitetsjusterte leveår. Det er mulig at svensk helseøkonomi ikke har hatt det korrektiv som Norge har hatt i Erik Nord.

Tross noen svakheter er dette en leseverdig bok som lett kan anbefales. Den gir mye lærdom på relativt få sider. Spørsmålet den potensielle kjøper bør stille seg, er om man skal velge en norsk eller svensk bok. Den norske helseøkonomen Jan Abel Olsen har utgitt en bok av omtrent samme omfang og med mye av det samme stoffet (1). De med interesse for internasjonale sammenlikninger vil kanskje velge Anell, mens de som er opptatt av rettferdighetsargumenter $i$ helsepolitikken, nok vil finne mer av interesse i Olsens bok. Dette valget kan vi trygt overlate til markedet!

\section{Ivar Sønbø Kristiansen}

Institutt forhelseledelse og helseøkonomi Universitetet i Oslo

\section{Litteratur}

1. Olsen JA. Helseøkonomi: Effektivitet og rettferdighet. Oslo: Cappelen Akademisk, 2006.

\section{Fedmebehandling på svensk - atferdsendring i praksis?}

\author{
Edlund K, Zethelius B, red \\ Fetma - Del 1 \\ Medicinsk behandling och kognitiv \\ beteendeterapi. $312 \mathrm{~s}$, tab, ill. Lund: \\ Studentlitteratur, 2009. Pris SEK 379 \\ ISBN 978-91-44-01892-8 \\ Edlund $\mathrm{K}$, Zethelius B, red \\ Fetma - Del 2 Patientmaterial \\ Behandling med kognitiv beteendeterapi. \\ 345 s, tab, ill. Lund: Studentlitteratur, 2009 \\ Pris SEK 393 \\ ISBN 978-91-44-05599-2
}

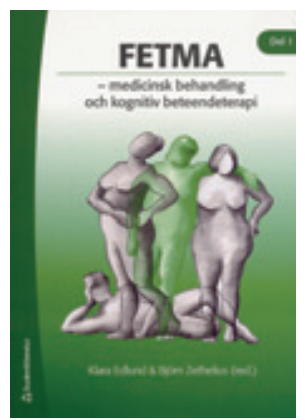

Redaktørene har solid praktisk og teoretisk bakgrunn i fedmebehandling, og de ønsker å videreformidle sin kunnskap til kolleger og annet helsepersonell som arbeider med behandling av fedme og fedmerelaterte sykdommer. Selv om boken er skrevet på svensk, er den i hovedsak lettlest. Den består av en generell del (Del 1), en manual for terapeuten (Del 2) og et pasienthefte.

I del 1 oppsummeres initialt årsaker til fedme, somatiske fedmerelaterte følgesykdommer samt psykologiske og psykososiale problemstillinger. Deretter følger en detaljert gjennomgang av forskjellige tradisjonelle, men aktuelle, behandlingsprinsipper som kostråd, lavkaloridiett, fysisk aktivitet, medikamenter og fedmekirurgi. I den siste delen av bind 1 gjennomgås kunnskapsgrunnlaget for og den praktiske gjennomføring av kognitiv atferdsterapi mot fedme. De fleste kapitlene innledes med en relevant kasuistikk og avsluttes med hvordan det gikk med pasienten. Det første bindet kan godt leses isolert og kan være spesielt nyttig for de som ønsker en kort og god oppsummering av dagens kunnskap innen fagfeltet.

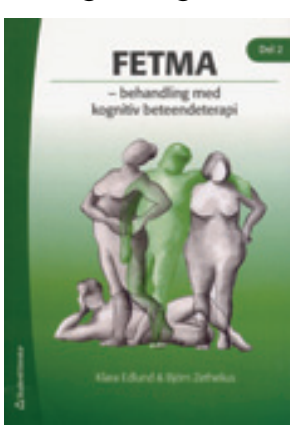
Del 2 er en trinnvis manual for psykologer/psykoterapeuter som beskriver i detalj hvordan en spesifikk metode (LIWE = Lifestyle Interventions for Weight management) innen kognitiv atferdsterapi kan brukes for å hjelpe pasienter med overvekt eller fedme til å forandre livsstilsrelatert atferd for på lang sikt å kunne leve med en 5-10\% lavere og/eller stabil vekt. Det første halve året legges det opp til 24 aktive behandlingssesjoner i gruppe og tre individuelle sesjoner der terapeuten har en aktiv og styrende rolle. Deretter følger en periode på minst ett år der pasientene aktiveres og overlates en større del av ansvaret for gjennomføringen av behandlingen. Pasienten forventes å jobbe med hjemmelekser bl.a. fra pasientheftet mellom sesjonene.

Bøkene er leseverdige og anbefales alle som jobber med fedme. Hvorvidt den spesifikke intervensjonsteknikken LIWE, med kognitiv atferdsterapi som teoretisk plattform, bør anbefales bredt implementert i fedmebehandling i Norge, er imidlertid mer usikkert. For det første mangler dokumentasjon som kan bekrefte at denne metoden gir bedre helsegevinst enn andre psykologiske intervensjonsteknikker. For det andre mangler studier som kan vise til langtidseffekter av psykologisk intervensjon på vektreduksjon og bedring av følgesykdom. Videre kan det hevdes at LIWE er noe instrumentell og har for liten vekt på individets selvregulering og motivasjon. Metoden fokuserer mye på «hvordan» i intervensjonen, og lite på «hvorfor», som omhandler oppbygging av individets egenmotivasjon for endring. Et eksempel på en alternativ intervensjon er endringsfokusert rådgivning (motivational interviewing). Kanskje det nettopp er individets indre motivasjon som blir avgjørende for etterlevelse av nye kognitive og atferdsmessige strategier. Avslutningsvis kan gjennomførbarhet og kostnader være mulige begrensninger for bred implementering av en slik kompetansekrevende intervensjon.

\section{Jøran Hjelmesæth \\ Hege Gade}

Sykehuset i Vestfold

Senter for sykelig overvekt i Helse Sør-Øst Tønsberg 